\title{
Article \\ Use of Symbiotic Fungi to Reduce the Phytotoxic Effect of DCD Nitrification Inhibitors in Lettuce
}

\author{
Akbar Padash ${ }^{1}$ (), Rasoul Azarmi ${ }^{1, *}$, Ali Ashraf Soltani Toularoud ${ }^{2}$, Behrooz Esmailpour ${ }^{1}$ and Cristina Cruz ${ }^{3, * *(1)}$ \\ 1 Department of Horticulture, Faculty of Agriculture, University of Mohaghegh Ardabili, \\ Ardabil 56199-13131, Iran; a.padash@uma.ac.ir (A.P.); behsmaiel@uma.ac.ir (B.E.) \\ 2 Department of Soil Science and Engineering, Faculty of Agriculture and Natural Resources, \\ University of Mohaghegh Ardabili, Ardabil 56199-13131, Iran; ali_soltani_t@uma.ac.ir \\ 3 Center for Ecology and Plant Biology, Department of Plant Biology, Faculty of Sciences, University of Lisbon, \\ 1649-004 Lisbon, Portugal \\ * Correspondence: r_azarmi@uma.ac.ir (R.A.); ccruz@fc.ul.pt (C.C.)
}

check for

updates

Citation: Padash, A.; Azarmi, R.;

Ashraf Soltani Toularoud, A.;

Esmailpour, B.; Cruz, C. Use of Symbiotic Fungi to Reduce the Phytotoxic Effect of DCD

Nitrification Inhibitors in Lettuce.

Agriculture 2022, 12, 251.

https: / /doi.org/10.3390/

agriculture12020251

Academic Editor: Nieves

Goicoechea

Received: 11 December 2021

Accepted: 19 January 2022

Published: 9 February 2022

Publisher's Note: MDPI stays neutral with regard to jurisdictional claims in published maps and institutional affiliations.

Copyright: (C) 2022 by the authors. Licensee MDPI, Basel, Switzerland. This article is an open access article distributed under the terms and conditions of the Creative Commons Attribution (CC BY) license (https:// creativecommons.org/licenses/by/ $4.0 /)$
Abstract: Nitrification inhibitors are commonly used to prevent nitrate leaching. However, the use of nitrification inhibitors is not free of side-effects. Some may be absorbed by the plant and cause phytotoxicity or even affect the food chain. Therefore, a solution that limits the absorption of nitrification inhibitors and its accumulation by the plant may mitigate health and environmental issues potentially associated with high levels of nitrification inhibitors. This solution may relay in the modulation of the plant's metabolism through the interaction with specific fungal partners. This work tested the hypothesis that the symbiotic interaction between fungi and plant roots can reduce the destructive effects of the nitrification inhibitor Dicyandiamide (DCD) in plants by reducing the uptake of nitrification inhibitors. A greenhouse experiment was conducted, using a complete randomized block design, to test the effect of symbiotic fungi (plants inoculated with Piriformospora indica, Glomus etunicatum, and Glomus mosseae and noninoculated) on the phytotoxicity of DCD applied at four concentrations (0,5,50, and $100 \mathrm{mg} \mathrm{kg}^{-1}$ soil). Latuca sativa, cultivar Siyahoo, was selected for this experiment due to its economic value all over the world. The use of high DCD concentrations (100 $\mathrm{mg} \mathrm{kg}^{-1}$ soil) affected the leaf chlorophyll content and plant growth in a manner that was significantly mitigated by the symbiosis of the plant with the fungal partner. These results highlight the benefits of using symbiotic fungal inoculants as plant protectors against the phytotoxic effects of DCD.

Keywords: nitrification inhibitor; symbiotic fungi; Dicyandiamide; Latuca sativa

\section{Introduction}

Nitrate is one of the most important forms of nitrogen in agricultural soils. At any time, the soil nitrate concentration is the balance between the inputs (mainly fertilizer) and the outputs (biological transformations, biological immobilization and transformation, and leaching) where nitrifying microorganisms play a key role. In the soil, these organisms convert ammonium to nitrite and then nitrite to nitrate during the nitrification process [1]. Nitrate in soils is mainly lost through leaching, which, in addition to the loss of nitrogen, causes environmental pollution. One of the most important ways to control the amount of nitrate in the soil and reduce its loss is to use nitrification inhibitors (NIs). In fact, nitrification inhibitors are compounds that delay the bio-oxidation of ammonium to nitrite without affecting the oxidation of nitrite to nitrate [2]. This is carried out by preventing or interfering with the metabolism of bacteria that are effective in nitrite generation (such as Nitrosomonas) [3]. Thus far, several types of nitrification inhibitors have been marketed: 2-chloro-6-(trichloromethyl)-pyridine, dicyandiamide (DCD), and 3,4-dimethylpyrazole phosphate (DMPP) are examples of those widely used. Research shows that the use of nitrate inhibitors can have negative effects on other soil organisms (population of fungi 
and bacteria) and the plants grown in it [4]. Extensive studies have been performed on the toxicity of NIs such as DMPP toxicity on clover [5]. Zerulla et al. [6] observed that the application of $1.5 \mathrm{~kg} \mathrm{ha}^{-1}$ of DCD in lettuce causes severe leaf margin burns. In addition, the use of triazole compounds such as 1,2,4-Triazole (TZ), when applied in doses between 0.2 and $10 \mathrm{mg} \mathrm{L}^{-1}$, disrupts the nitrification process and can have a negative effect on other bacteria (aerobic and methane-oxidizing heterotrophic bacteria) [7].

In addition to having a direct effect on plant growth, symbiotic fungi can also protect plants against abiotic stresses through distinct mechanisms, increasing crop productivity and quality. Among these microorganisms, arbuscular and endophytic fungi able to form symbiosis with plant roots are the best characterized. They are known to increase plant resistance to biotic and abiotic stresses through several mechanisms, including the production of various metabolites [8]. P. indica is an important plant endophytic fungus that increases plant growth under normal conditions and stress under various mechanisms [9]. This microorganism strengthens the antioxidant defense system of plants, which plays an important role in stress tolerance, and induces disease resistance in plants by increasing the level of antioxidants to combat oxidative stress [10]. There are several reports of the relevance of mycorrhizal symbioses for the degradation of several contaminants. For instance, ryegrass inoculation with Glomus sp. reduces the impact of petroleum hydrocarbons, especially pyrine, on plant growth [11], and the inoculation of alfalfa with G. mosseae or G. etunicatum removed more than $98 \%$ of phenanthrene and $88 \%$ of pyrine accumulated in the plants [12].

According to the studies, there is a possibility of accumulation and increase in nitrification inhibitors in the soil, and, over the years, its amount increases in agricultural soils. The toxicity of nitrate inhibitors to soil biota, and the possibility of their accumulation in plant tissues grown in soils to which these substances are added, needs a solution, an issue that, to our knowledge, has not been researched. Due to the economic relevance of lettuce, and due to its high consumption as a leafy salad, and the broad use of DCD, this study aimed to investigate the role of mycorrhizal and endophytic fungi (Glomus mosseae, Glomus etunicatum, and P. indica) as possible tools to reduce the phytotoxicity of DCD. In addition, high concentrations of DCD were used to better understand the effects of the adverse accumulation of nitrification inhibitors.

\section{Materials and Methods}

\subsection{Experimental Design}

The experimental design was a factorial randomized block design including one plant species (lettuce, Latuca sativa, cultivar Siyahoo), four fungi treatments (G. etunicatum, G. mosseae, P. indica, and no inoculation), and four doses of $\operatorname{DCD}\left(0,5,50\right.$, and $100 \mathrm{mg} \mathrm{kg}^{-1}$ soil) with four replicates per treatment.

\subsection{Soil Preparation and Dicyandiamide Treatment}

A combined sample of a sandy loam soil (from 0 to $25 \mathrm{~cm}$ layer) was collected from the surface horizon of the Mohaghegh Ardabili University Campus farm and then physicochemically characterized: $68 \%$ sand, $20 \%$ silt, $12 \%$ clay, $1.2 \%$ organic matter, $0.05 \%$ total $\mathrm{N}, 7 \mathrm{mg} \mathrm{kg}^{-1}$ available $\mathrm{P}, 35 \mathrm{mg} / \mathrm{kg}$ available $\mathrm{K}, 0.7 \mathrm{mg} / \mathrm{kg}$ total $\mathrm{Cd}$, a $\mathrm{pH}$ of 7.3 , and $1.3 \mathrm{ds} \mathrm{m}^{-1} \mathrm{EC}$. Then, DCD powder (Sigma-Aldrich, Burlington, MA, USA) was added to the surface of $1 \mathrm{~kg}$ of air-dried soil samples to provide the following concentrations: 0 , 5,50 , and $100 \mathrm{mg} \mathrm{kg}^{-1}$ soil [13]. Soil amended with inhibitors was thoroughly mixed to achieve a homogeneous DCD soil concentration. Nitrogen as $\left(\mathrm{NH}_{4}\right)_{2} \mathrm{SO}_{4}(\mathrm{Merck}$, Darmstadt, Germany) was applied in aqueous solution at a rate of $40 \mathrm{mg} \mathrm{kg}^{-1}$ soil [14]. An amount of $10 \mathrm{~kg}$ of soil, with the distinct DCD concentrations, was transferred into pots with a diameter of $25 \mathrm{~cm}$ and a depth of $40 \mathrm{~cm}$. 


\subsection{Plant Growth Conditions}

Lettuce seeds (Lactuca sativa cv. Siyahoo) were prepared from the Seed Bank Institute of Karaj, Iran. The seeds were sown in trays containing peat moss. When the seedlings reached the two-leaf stage, they were transferred to pots with nitrification inhibitors and inoculated using the fungi $\left(22 / 18{ }^{\circ} \mathrm{C}\right.$ day /night cycle, $60-70 \%$ relative humidity, and a photoperiod of $14 \mathrm{~h}$ ).

\subsection{Seed Inoculation with Fungi}

P. indica was cultured in Petri dishes on a Hill and Käfer medium [15]. The plates were placed in a growth chamber at $29 \pm 1{ }^{\circ} \mathrm{C}$ in the dark for 2 weeks. To impose the fungal treatment, one fungal plug of $10 \mathrm{~mm}$ in diameter was placed at a distance of $1 \mathrm{~cm}$ below the roots of 10-days-old lettuce seedlings.

Mycorrhizal fungi were prepared at the Department of Soil Science, University of Tabriz (Professor Nasser Aliasgharzad). The inocula of G. mosseae and G. etunicatum fungals were added to the soil of the pot, and $1 \mathrm{~cm}$ of soil was covered and then lettuce seedlings were placed on it. The number of spores in the inoculum was 33-35 per gram and root colonization was $78.8 \%$ [16].

\subsection{SEM and Plant Growth Measurements}

After 45 days of planting, the shoots of lettuce were harvested and the roots were separated from the soil substrate. Then, some young leaves were selected for imaging using scanning electron microscopy (SEM). The samples selected for imaging were dried in the shade and then imaging was performed using an electron microscope in the Department of Chemistry, Mohaghegh Ardabili University. Then, the stomata area was calculated using the obtained photos. AutoCAD software was used to measure the stomata area.

The shoots and roots were rinsed with distilled water, wiped with tissue paper, and weighted. The shoots and roots were separated, the shoot height and leaf number per plant were determined, and they were finally dried at $75^{\circ} \mathrm{C}$ for $48 \mathrm{~h}$ in order to determine the dry weights (shoots and roots). Some root segments were placed in 50\% ethanol to determine the root colonization.

\subsection{Root Colonization}

The Phillips and Hayman [17] method was used to color the root and determine its colonization. The roots were heated in $10 \% \mathrm{KOH}$ solution for $5 \mathrm{~min}$ and then washed under water. Root samples with $1 \% \mathrm{HCl}$ were acidified for $1 \mathrm{~min}$, immersed in $20 \%$ trypan blue staining solution, and heated for $10 \mathrm{~min}$. From the stained samples, 30 root segments $(1 \mathrm{~cm}$ long) per plant were cut and observed with a light microscope (Olympus BH-2) at 20x. Root colonization was determined according to the gridline intersection method [18]. In this technique, the percentage of root colonization per plant was determined by dividing the total number of colonized root fragments (either with arbuscules, vesicles, or hyphae) by the total number of root pieces examined $\times 100$.

\subsection{Total Chlorophyll and Carotenoids Contents}

Measurements of chlorophyll and carotenoids were performed using Arnon's method [19]. Chlorophyll and carotenoids were extracted from a sample of $1 \mathrm{~g}$ of fresh leaves in acetone $80 \%(v / v)$. Absorption was measured at 645 and $663 \mathrm{~nm}$ for chlorophyll and 480 and 510 for carotenoids using a spectrophotometer (UV-600). The concentration of total chlorophyll and carotenoids was expressed as $\mu \mathrm{g} \mathrm{mL}^{-1}$ fresh weight and determined using the formula:

$$
\begin{gathered}
\text { Chlorophyll } \mathrm{a}=[15.65(\mathrm{~A} 663)-7.340(\mathrm{~A} 645)] \\
\text { Chlorophyll } \mathrm{b}=[27.05(\mathrm{~A} 645)-11.21(\mathrm{~A} 663)] \\
\text { Total chlorophyll }=[20.2(\mathrm{~A} 645)+8.02(\mathrm{~A} 663)] \times \mathrm{V} / \mathrm{W} 1000
\end{gathered}
$$




\section{Carotenoids $=[7.6(\mathrm{~A} 480)-1.49(\mathrm{~A} 510)] \times \mathrm{V} / \mathrm{W} 1000$}

\subsection{Measurement of DCD in Lettuce Leaves}

DCD concentration was measured using the method of Kim et al. [20]. To do this, first, a young leaf was selected from each plant (leaf sample should be the same in all plants). Then, $1 \mathrm{~g}$ of leaves was weighed and $40 \mathrm{~mL}$ of deionized water was added to it and placed on a shaker for $20 \mathrm{~min}$. At the end of $20 \mathrm{~min}$, the plant sample was completely crushed using a mortar and the resulting sample was passed through Whatman filter paper. Each of the $5 \mathrm{~mL}$ of the filtrate obtained from the two extractions of surface residues above was acidified with $0.2 \mathrm{~mL}$ of $0.66 \mathrm{M} \mathrm{H}_{2} \mathrm{SO}_{4}$ and allowed to stand for $30 \mathrm{~min}$ before centrifuging $(10,000 \mathrm{rpm}$ for 15 min equivalent to $11,180 \times g)$ to remove precipitated material and optimize the $\mathrm{pH}$ to the HPLC conditions. The concentration of DCD in the acidified supernatant was determined on a Waters 2695 HPLC using a cation- $\mathrm{H}$ guard column $(30 \times 4.6 \mathrm{~mm}$ internal diameter; ID) with a $0.025 \mathrm{M} \mathrm{H} 2 \mathrm{SO} 4$ mobile phase at a flow rate of

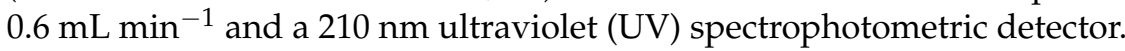

\subsection{Statistical Analysis}

Two-way ANOVA was performed on all experimental data using IBM SPSS version 23 software (Chicago, IL, USA). The variance was related to the main factors (symbiotic fungi and DCD) and to the interaction between them. The differences between means were determined using Duncan's Multiple Range Test at 0.05 and 0.01 probability levels.

\section{Results and Discussion}

\subsection{Effect of DCD on Root Colonization by P. indica, G. etonicatum, and G. mosseae}

Most arable soils are now under severe human management, and various agricultural and horticultural chemicals (such as pesticides, fungicides, and nitrification inhibitors) are applied to maintain and/or increase soil productivity [21]. Soil microbiota are commonly exposed to these chemical inputs, which have potential effects on the abundance, structure, and functionality of each community and its interactions with the communities of other microorganisms [22,23]. For instance, nitrification inhibitors, such as 3,4-dimethylpyrazole phosphate (DMPP), may interact with the nitrification community and, at the same time, reduce or suppress soil nitrogenase activity [24]. Shi et al. [25] also found that nitrification inhibitor phosphate DMPP inhibited nitrifier-induced denitrification, which is an important source of soil nitrous oxide. However, due to the nature of their physiology and their involvement in decomposition and nutrient turnover, fungi may be more responsive to soil inputs than another biota. Yet, very few studies have been performed to elucidate the impacts of agrochemical use on soil fungal communities $[22,26]$ and on the symbiotic relationships between plants and fungi $[27,28]$.

Our results clearly show that soil DCD concentration had a significant $(p<0.01)$ effect on the colonization of lettuce root by P. indica, G. etonicatom, and G. mosseae (Table 1). No significant differences were observed for the root colonization by each fungi at the same DCD concentration, and all the fungi presented the same root colonization pattern: a decrease in the colonization rate from 0 to 5 , no big differences from 5 to 10 , followed by a sharp decrease in the colonization rate from 50 to $100 \mathrm{mg} \mathrm{kg}^{-1} \mathrm{DCD}$, which, according to the impact that endophytic (P. indica) and mycorrhizal (G. etunicatum and G.mosseae) fungi have on soil and plants, can anticipate changes at the level of soil and plant functionality such as those found by Yu et al. [29] and Marschner [30].

The mechanisms through which nitrification inhibitors may reduce root colonization are debatable, but some studies have pointed to direct and undirect effects related to the increase in soil $\mathrm{NH}_{4}{ }^{+}$concentration associated with nitrification inhibition. It has been observed that high soil $\mathrm{NH}_{4}{ }^{+}$concentration inhibits spore germination of arbuscular mycorrhizal fungi [31], while Marschner [30] found that the increase in soil $\mathrm{NH}_{4}{ }^{+}$concentration caused mitochondrial swelling and cracking of plant root cells, which resulted in reduced root colonization by mycorrhizal fungi. The hypotheses of the inhibitory effect of DCD 
on fungal root colonization being mediated by the toxic effect of ammonium on plant development may be supported by the observed effect of the soil concentration of DCD on plant root development (Table 1). Figure 1 also shows root colonization by symbiotic fungi.

Table 1. Effect of distinct DCD concentrations on root colonization by Piriformospora indica (P.i), Glomus etunicatum (G.e), and Glomus mosseae (G.m), shoot dry weight, shoot height, leaf number, root fresh weight, and root length of lettuce plants.

\begin{tabular}{|c|c|c|c|c|c|c|c|}
\hline \multicolumn{2}{|c|}{ Treatment } & \multicolumn{6}{|c|}{ Parameters } \\
\hline $\begin{array}{l}\text { DCD } \\
\left(\mathrm{mg} \mathrm{kg}^{-1}\right. \\
\text { Dry Soil) }\end{array}$ & $\begin{array}{l}\text { Symbiotic } \\
\text { Fungi }\end{array}$ & $\begin{array}{l}\text { Root } \\
\text { Colonization } \\
(\%)\end{array}$ & $\begin{array}{l}\text { Shoot Dry } \\
\text { Weight (g } \\
\text { plant }^{-1} \text { ) }\end{array}$ & $\begin{array}{l}\text { Shoot Height } \\
(\mathrm{cm})\end{array}$ & $\begin{array}{l}\text { Leaf } \\
\text { Number (No } \\
\text { plant }^{-1} \text { ) }\end{array}$ & $\begin{array}{l}\text { Root Fresh } \\
\text { Weight (g } \\
\text { plant }^{-1} \text { ) }\end{array}$ & $\begin{array}{l}\text { Root Length } \\
(\mathrm{cm})\end{array}$ \\
\hline \multirow[t]{4}{*}{ Control } & 0 & ND & $14.1^{\mathrm{de}} \pm 1.2$ & $29.8^{\text {defg }} \pm 0.2$ & $31.7^{\text {efg }} \pm 0.2$ & $43.4^{\mathrm{e}} \pm 1.7$ & $41.5^{\text {hi }} \pm 2.3$ \\
\hline & $+P . i$ & $82.2^{\mathrm{a}}$ & $20.6^{\mathrm{ab}} \pm 2.1$ & $37.1^{\mathrm{a}} \pm 0.8$ & $38.5^{\mathrm{a}} \pm 0.3$ & $55.9^{a b} \pm 1$ & $50.6^{\text {def }} \pm 3.1$ \\
\hline & + G.e & $76.2^{a b}$ & $15.6^{\mathrm{cd}} \pm 0.5$ & $33.1^{b c} \pm 0.4$ & $34.5^{b c d} \pm 0.7$ & $51.0^{\mathrm{bcd}} \pm 2.4$ & $53.2^{\mathrm{cd}} \pm 1.2$ \\
\hline & $+G \cdot m$ & $77.4^{\mathrm{ab}}$ & $13.7^{\mathrm{de}} \pm 1.3$ & $30.7^{\text {de }} \pm 1.1$ & $33.4^{\mathrm{cd}} \pm 0.3$ & $48.7^{\text {cde }} \pm 1.5$ & $51.5^{\text {def }} \pm 3.2$ \\
\hline \multirow[t]{4}{*}{5} & 0 & ND & $13.7^{\text {de }} \pm 2.3$ & $30.1^{\text {def }} \pm 0.9$ & $31.9^{\text {ef }} \pm 0.4$ & $49.5^{\text {cde }} \pm 1.7$ & $46.1^{\mathrm{fgh}} \pm 1.6$ \\
\hline & $+P . i$ & $67.4^{b c}$ & $21.8^{\mathrm{a}} \pm 3.4$ & $34.3^{b} \pm 0.2$ & $35.7^{\mathrm{abc}} \pm 0.5$ & $58.7^{a} \pm 2.6$ & $66.5^{\mathrm{a}} \pm 2.1$ \\
\hline & + G.e & $66.2^{b c}$ & $17.7^{\mathrm{bcd}} \pm 1.5$ & $31.5^{\mathrm{cd}} \pm 0.6$ & $37.0^{\mathrm{ab}} \pm 0.7$ & $55.5^{\mathrm{ab}} \pm 1.3$ & $60.2^{b} \pm 4.5$ \\
\hline & $+G \cdot m$ & $68.1^{b c}$ & $16.7^{\mathrm{bcd}} \pm 2$ & $30.0^{\text {def }} \pm 0.7$ & $32.9^{\text {def }} \pm 0.8$ & $47.5^{\mathrm{cde}} \pm 2.2$ & $52.8^{\text {cde }} \pm 1.6$ \\
\hline \multirow[t]{4}{*}{50} & 0 & ND & $10.9^{\text {ef }} \pm 1.35$ & $28.0^{g} \pm 0.3$ & $29.1^{\mathrm{gh}} \pm 0.1$ & $38.7^{\mathrm{f}} \pm 1.8$ & $39.2^{\mathrm{i}} \pm 2.4$ \\
\hline & $+P . i$ & $60.0^{\mathrm{cd}}$ & $15.7^{\mathrm{cd}} \pm 3.1$ & $29.9^{\text {def }} \pm 1.3$ & $31.0^{\text {efgh }} \pm 0$ & $51.2^{b c d} \pm 1.3$ & $57.2^{\mathrm{bc}} \pm 1.6$ \\
\hline & + G.e & $52.7^{\mathrm{e}}$ & $15.3^{\mathrm{cd}} \pm 1.4$ & $30.3^{\text {de }} \pm 0.8$ & $31.7^{\text {efg }} \pm 0.5$ & $51.5^{b c} \pm 1.3$ & $55.2^{\mathrm{bcd}} \pm 2.2$ \\
\hline & $+G \cdot m$ & $64.4^{\mathrm{cd}}$ & $11.3^{\text {ef }} \pm 1.8$ & $29.1^{\text {efg }} \pm 0.6$ & 31.9 ef \pm 0.6 & $46.0^{\text {cde }} \pm 2.5$ & $47.8^{\text {efg }} \pm 33$ \\
\hline \multirow[t]{7}{*}{100} & 0 & ND & $5.7^{\mathrm{g}} \pm 0.71$ & $25.2^{\mathrm{h}} \pm 1.1$ & $20.5^{\mathrm{i}} \pm 0.2$ & $34.0^{\mathrm{f}} \pm 3.1$ & $29.5^{\mathrm{j}} \pm 4.1$ \\
\hline & $+P . i$ & 43.2 ef & $13.8^{\mathrm{de}} \pm 1.6$ & $29.7^{\text {defg }} \pm 0.6$ & $29.2^{\mathrm{gh}} \pm 0.3$ & $48.2^{\text {cde }} \pm 1.2$ & $50.5^{\text {def }} \pm 3.7$ \\
\hline & + G.e & $45.8^{\mathrm{e}}$ & $13.7^{\mathrm{de}} \pm 0.8$ & $29.5^{\text {efg }} \pm 0.4$ & $30.1^{\mathrm{fgh}} \pm 0.7$ & $46.2^{\text {cde }} \pm 1.3$ & $51.0^{\text {def }} \pm 2.3$ \\
\hline & $+G \cdot m$ & $32.3^{\text {ef }}$ & $8.3^{\mathrm{fg}} \pm 1.02$ & $28.2^{\mathrm{fg}} \pm 0.7$ & $28.4^{h} \pm 0.6$ & $45.4^{\mathrm{de}} \pm 2.1$ & $43.5^{\text {ghi }} \pm 1.1$ \\
\hline & Inhibitor & $* *$ & $* *$ & $* *$ & $* *$ & $* *$ & ** \\
\hline & fungi & $* *$ & $* *$ & $* *$ & $* *$ & $* *$ & $* *$ \\
\hline & In. $\times$ Fu & $* *$ & $*$ & $* *$ & $* *$ & $*$ & $*$ \\
\hline
\end{tabular}

Values are the mean $\pm S E, n=4$. The same letter within each column indicates no significant difference among treatments using Duncan's Multiple Range Test. ns: not significant. ${ }^{*} p<0.05,{ }^{* *} p<0.01$.
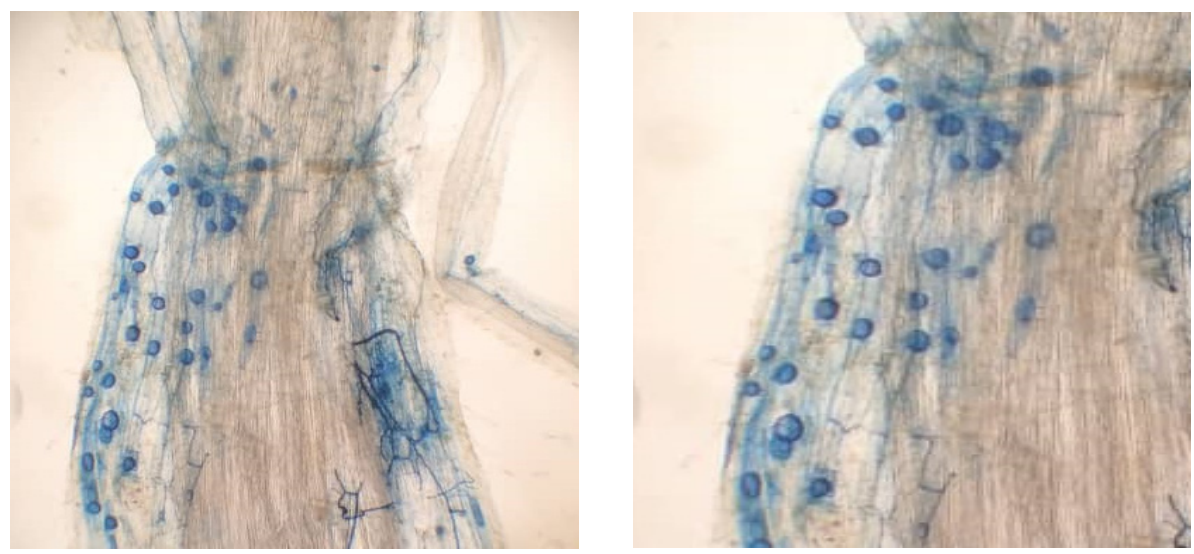

Figure 1. Images of root colonization by symbiotic fungi in the roots of lettuce.

\subsection{Root Fresh Weight and Root Length}

Our results showed that root fresh weight per plant was not significantly affected by the fungal colonization when DCD was not present in the soil. However, in the presence of DCD, the inhibition of root fresh weight was more evident in plants that were not colonized by fungi, especially at high DCD concentrations (Table 1). DCD affected root length in a similar way as root fresh weight. In general, plants inoculated with symbiotic fungi had more developed root systems than noninoculated plants, and fungal colonization protected 
roots from DCD inhibition. In fact, if we think that the symbiotic fungi under study are good ammonium scavengers [32], it can be argued that they may protect plant roots from ammonium toxicity. If the inhibitory effect of DCD on root colonization by symbiotic fungi is mediated by the ammonium toxicity at the root level, then the effect of DCD on fungal root colonization should differ from plant to plant according to the plant tolerance to ammonium nutrition [33].

As DCD may be absorbed by plant roots [34-36], one could argue about a direct effect of DCD on plant metabolism. However, this has to be a direct effect of the DCD itself as plants are not able to metabolize it [35] and the DCD taken up by plant roots accumulates in the roots or travels to the upper organs and accumulates there [34]. This brings the possibility of DCD affecting shoot metabolic activities, including photosynthesis, and by decreasing the carbon available to exchange with the fungi [35], affecting the root colonization by the symbiotic fungi (and the entire plant microbiota).

\subsection{The Effect of DCD on Shoot Development}

Without DCD, the symbiosis with P. indica stimulated, and those with G. etunicatum and G. mosseae did not significantly affect, shoot development of lettuce plants $(p<0.05)$. However, in the presence of DCD, the symbiosis with P. indica or with G. etunicatum was more effective in preventing the inhibitory effect of DCD than that with G. mosseae. Without the symbiotic partner, increasing the soil DCD concentration from 0 to $100 \mathrm{mg} / \mathrm{kg}$ decreased the shoot fresh and dry weights but increased the shoot fresh weight to dry weight ratio by about $50 \%$ (from 19.5 to 30.7 ), implying a much higher level of water retention in the leaf. Combining this observation with the fact that no stomata closure was observed in response to DCD treatment, it can be inferred that the water continuum between soil-plant and atmosphere was not disrupted by DCD. Thus, DCD did not cause water stress to the lettuce plants, which is consistent with the findings of Zerulla et al. [6].

Symbiotic fungi (and other biofertilizers) may promote shoot development under stress conditions $[37,38]$ by ameliorating plant nutrition or stress. The effect of symbiotic fungi in improving shoot development in the presence of DCD was particularly evident for Piriformospora indica (Figures 2 and 3). Symbiotic fungi such as P. indica and G. etunicatum may increase the production of photosynthetic pigments or reduce their degradation by helping the plant to overcome the stress conditions, in this case, driven by high DCD conditions [39,40]. Growth inhibition and reduction in leaf chlorophyll (Figures 4 and 5) by DCD have been observed for plants grown under diverse conditions [41].

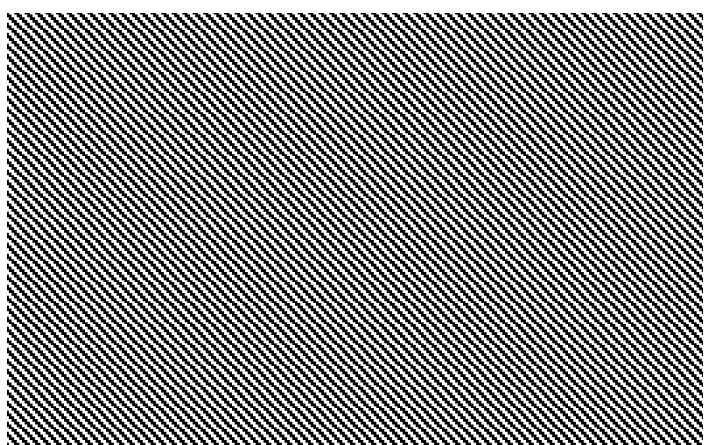

Figure 2. The mean effect of P. indica, G. etunicatum, and G. mosseae in lettuce plant fresh weight. (The means refer to four repetitions \pm SD. Different letters for each parameter indicate significant differences assessed $(p<0.05)$.)

Concentrations of 50 and $100 \mathrm{mg} \mathrm{kg}^{-1}$ DCD increased leaf carotenoid concentration by $34 \%$ and $60 \%$, respectively, compared to control plants (Figure 6). Carotenoids are defense compounds with the role of antioxidants that neutralize the harmful effects of reactive oxygen species formed in excess under stress conditions [42]. Altogether, the decrease 
in leaf chlorophyll concentration and the increase in leaf carotenoid concentration may indicate that DCD is a cause of leaf oxidative stress.

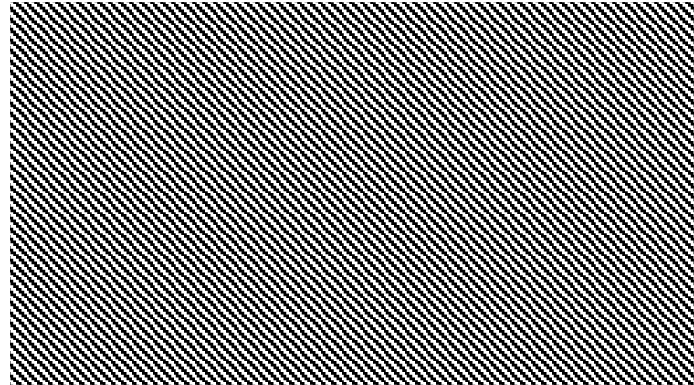

Figure 3. The main effect of dicyanodiamide in lettuce plant fresh weight. (The means refer to four repetitions \pm SD. Different letters for each parameter indicate significant differences assessed $(p<0.05)$.)

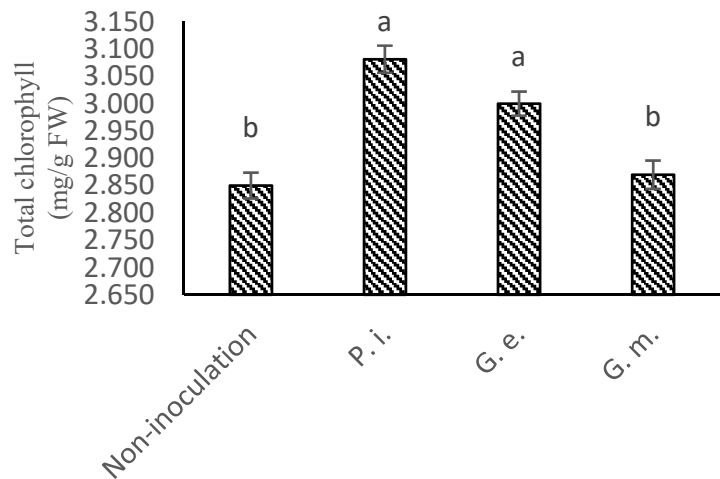

Figure 4. The mean effect of P. indica, G. etunicatum, and G. mosseae in leaves of lettuce on total chlorophyll content. (The means refer to four repetitions \pm SD. Different letters for each parameter indicate significant differences assessed $(p<0.05)$.)

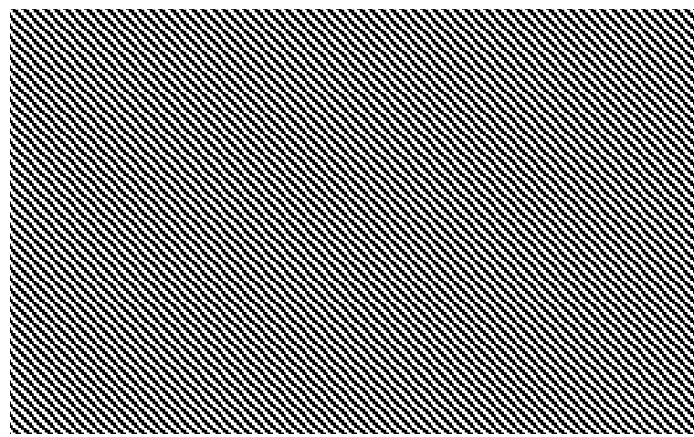

Figure 5. The main effect of dicyanodiamide in leaves of lettuce on total chlorophyll content. (The means refer to four repetitions $\pm \mathrm{SD}$. Different letters for each parameter indicate significant differences assessed $(p<0.05)$.)

\subsection{Dicyandiamide in the Leaves}

Leaf analyses showed that DCD can accumulate in lettuce leaves, especially when present at high concentrations in the root medium, and those symbiotic fungi may decrease this accumulation (Figure 7). P. indica was more efficient in restraining leaf DCD concentrations than G. etunicatum or G. mosseae, showing that at least some fungi may be relevant to reduce the phytotoxicity of nitrification inhibitors. However, the mechanism through which the fungi act is not clear yet [43]. Fungi may help the plant to overcome the stress caused by high DCD concentrations, but they may also accelerate DCD degradation in the soil or inside the plant $[2,44,45]$. Two independent experiments performed by Binet et al. [46] and Aranda et al. [47] showed that mycorrhiza significantly reduced the concentration of anthracene in plants by $20-40 \%$ compared to the control. The work by Zhou et al. [48] 
highlighted the capacity of mycorrhizal fungi to protect Medicago sativa plants against the toxic effects of polycyclic aromatic hydrocarbon. It is possible that pollutant compounds such as DCD adsorb to the fungal cell walls, which would decrease the free concentration of the compounds to be absorbed by the plant [43]. Figure 8A-M show the result of HPLC, which is given below to complete the topic and increase understanding.

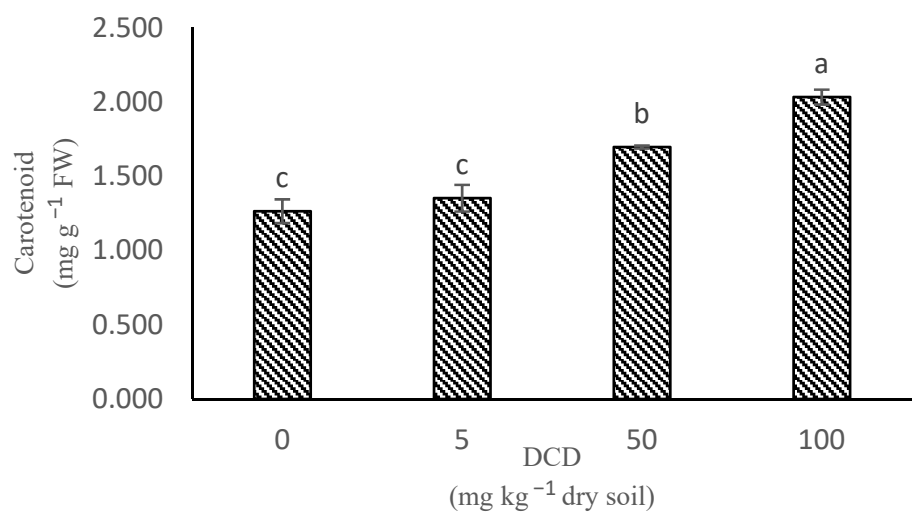

Figure 6. The main effect of dicyanodiamide in leaves of lettuce on carotenoid content. (The means refer to four repetitions $\pm \mathrm{SD}$. Different letters for each parameter indicate significant differences assessed $(p<0.05)$.)

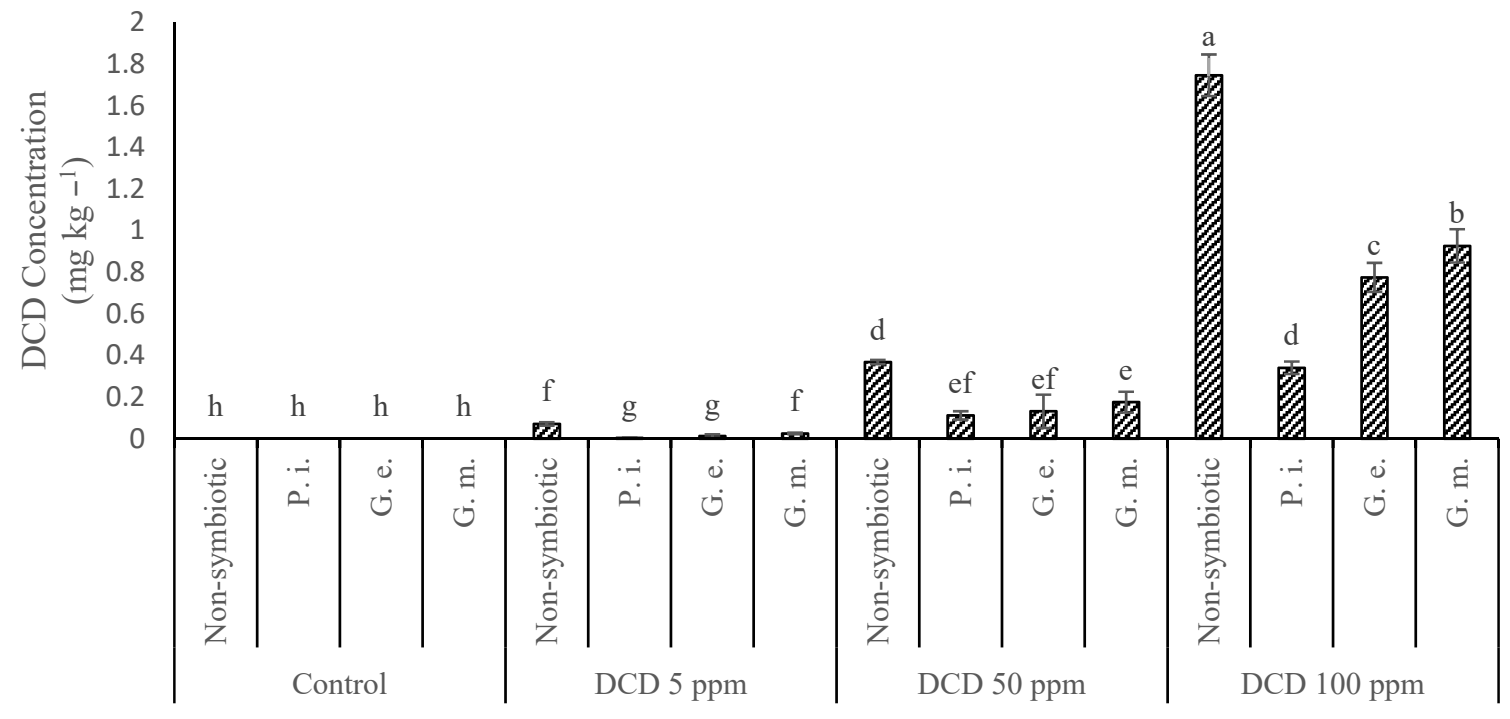

Figure 7. Effect of Piriformospora indica, Glomus mosseae, and Glomus etunicatum on the dicyandiamide content under different concentrations of dicyandiamide nitrification inhibitor in lettuce. (The means refer to four repetitions \pm SD. Different letters for each parameter indicate significant differences assessed $(p<0.05)$.)

\subsection{Effect of Dicyandiamide on Stomatal Behavior}

In the present study, no stomata closure was observed in response to DCD treatment (Figure 9). Researchers have shown that the presence of substances such as salt [49], heavy metals [50,51], phytohormones [52], and temperature changes and drought can affect the behavior of leaf stomata and the opening and closing of guard cells. However, the effect of nitrification inhibitors on plant leaf stomata has not been studied. In this study, the presence of high amounts of DCD caused the leaf stomata of lettuce to close. Nitric oxide (NO) affects various physiological functions, increasing plant tolerance to environmental stresses including salinity, toxic metals, and high and low temperatures by affecting the opening and closure of plant stomata $[49,50,53]$. Wu et al. [54] reported for the first time that the use of nitrification inhibitors prevents the production of $\mathrm{N}_{2} \mathrm{O}$ and $\mathrm{NO}$ greenhouse 
gases in the soil by acting on the bacteria that perform nitrification. Therefore, it is likely that DCD reduces NO concentration in the plant by inhibiting NO production and does not close the stomata. According to the results of previous studies and the results of the present experiment, reducing NO reduces plant growth.

\subsection{Stomata Area in the Leaves}

Analysis of the pore area of the leaf stomata showed that DCD can reduce the pore area of the stomata in lettuce leaves, especially when present in high concentrations in the root environment, and symbiotic fungi may increase this stomata area (Table 2). The use of $P$. indica increased the pore stomata area per leaf compared to control plants. In addition, the lowest pore stomata area was presented by plants that were treated with $100 \mathrm{mg} \mathrm{kg}^{-1}$ DCD and without the use of symbiotic fungi (Table 2). The concentration of $5 \mathrm{mg} \mathrm{kg}^{-1}$ in all treatments with control plants was not significantly different, except for the interaction of $5 \mathrm{mg} \mathrm{kg}^{-1} \mathrm{DCD}$ with $P$. indica. Vahabi et al. [55] reported that $P$. indica reduces stomata closure and plays an important role in increasing pore stomata size.

Table 2. Effect of Piriformospora indica, Glomus mosseae, and Glomus etunicatum on the stomata pore area $\left(\mu \mathrm{m}^{2}\right)$ under different concentrations of DCD in lettuce.

\begin{tabular}{lllll}
\hline & - & $+P . i$. & + G. $\boldsymbol{e}$. & G. $\boldsymbol{m}$. \\
\hline Control & $78.6^{\mathrm{b}} \pm 3.4$ & $86.3^{\mathrm{a}} \pm 5.3$ & $79.3^{\mathrm{b}} \pm 2.6$ & $78.8^{\mathrm{b}} \pm 3.6$ \\
DCD 5 mg kg & $78.7^{\mathrm{b}} \pm 5.6$ & $86.1^{\mathrm{a}} \pm 4.6$ & $79^{\mathrm{b}} \pm 3.1$ & $79.2^{\mathrm{b}} \pm 2.6$ \\
DCD 50 mg kg & $75.1^{\mathrm{c}} \pm 2.4$ & $75.4^{\mathrm{c}} \pm 3.6$ & $74.8^{\mathrm{c}} \pm 2$ & $75.3^{\mathrm{c}} \pm 3.2$ \\
DCD 100 mg kg & $64.3^{\mathrm{f}} \pm 4.1$ & $71.3^{\mathrm{d}} \pm 2.6$ & $68.6^{\mathrm{e}} \pm 1.2$ & $67.1^{\mathrm{e}} \pm 2.5$ \\
\hline
\end{tabular}

DCD: Dicyandiamide, + P. i: Piriformospora indica, + G. e: G. etunicatum, and G. m: G. mossea. Values are mean \pm SE $\mathrm{n}=5$. The same letter within each column indicates no significant difference among treatments using Duncan's Multiple Range Test.

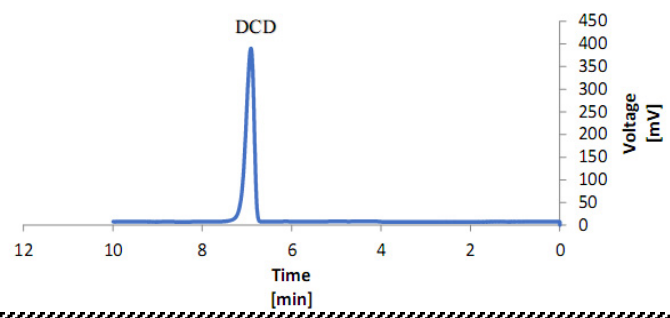

(A)

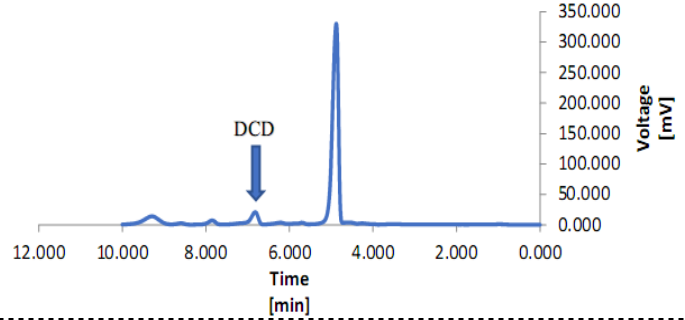

(B)

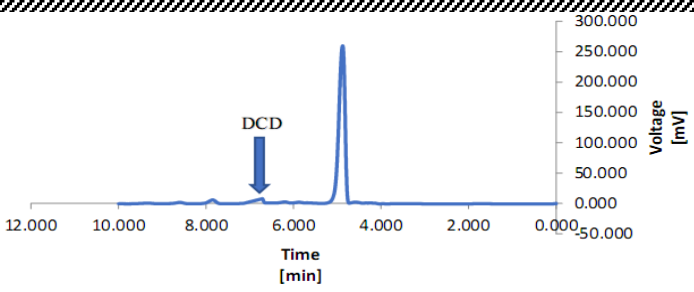

(D)

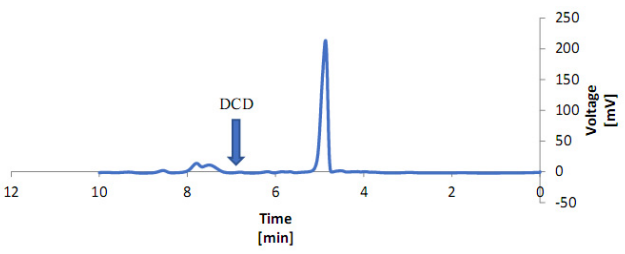

(C)

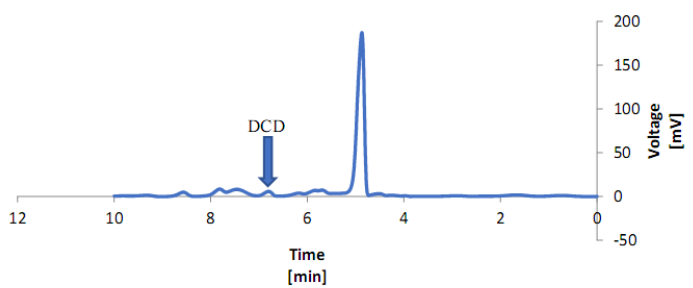

(E)

Figure 8. Cont. 


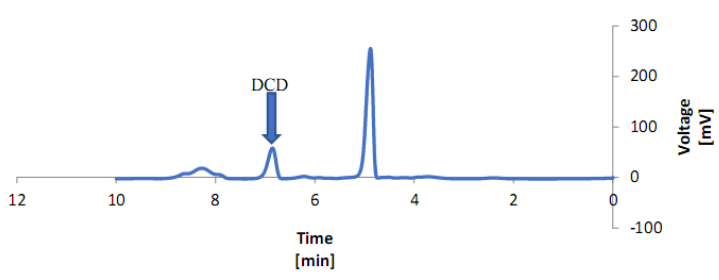

(F)

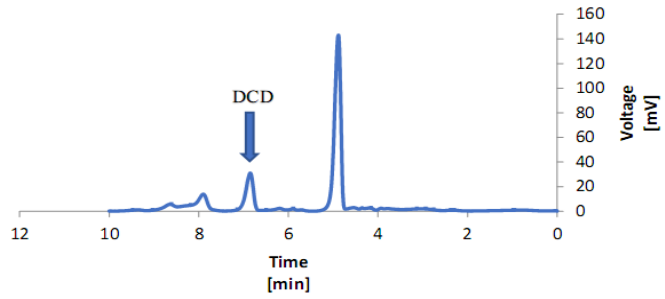

(H)

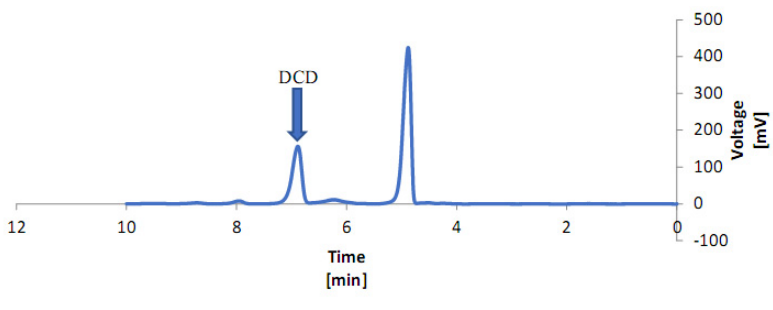

(J)

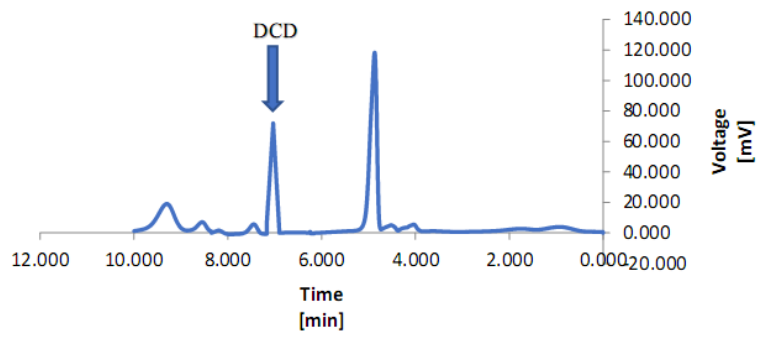

(L)

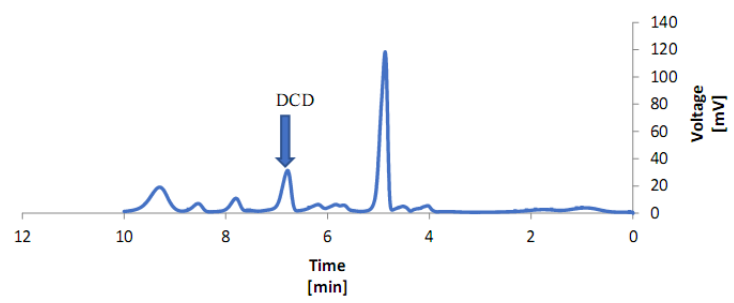

(G)

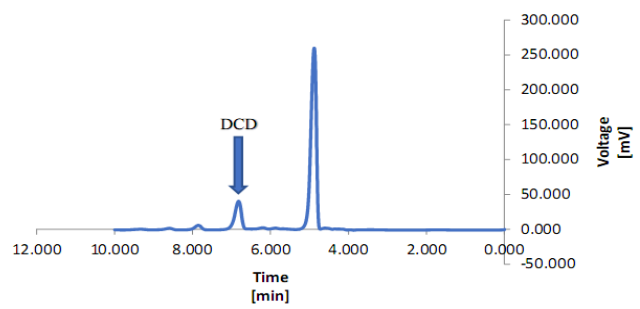

(I)

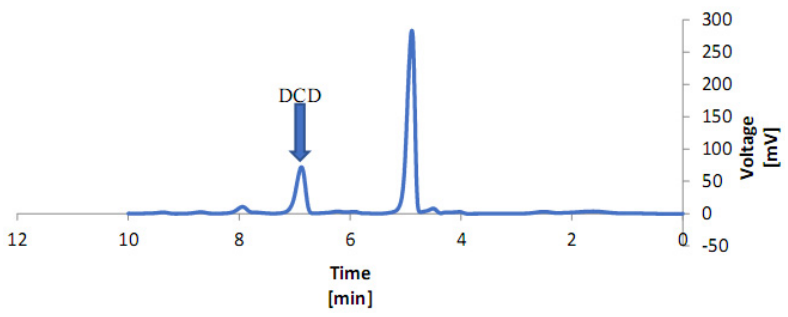

(K)

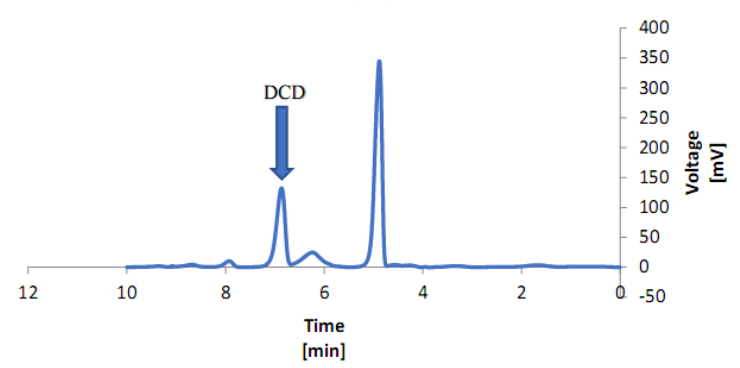

(M)

Figure 8. Effect of Piriformospora indica, Glomus etunicatum, and Glomus mosseae on dicyandiamide content in Lettuce leaves. (A) Standard chart of the dicyandiamide, (B) $5 \mathrm{mg} \mathrm{kg}^{-1}$ of dicyandiamide, (C) Piriformospora indica $+5 \mathrm{mg} \mathrm{kg}^{-1}$ of dicyandiamide, (D) Glomus etunicatum $+5 \mathrm{mg} \mathrm{kg}^{-1}$, (E) Glomus mosseae $+5 \mathrm{mg} \mathrm{kg}^{-1}$ of dicyandiamide, (F) $50 \mathrm{mg} \mathrm{kg}^{-1}$ of dicyandiamide, (G) Piriformospora indica $+50 \mathrm{mg} \mathrm{kg}^{-1}$ of dicyandiamide, (H) Glomus etunicatum $+50 \mathrm{mg} \mathrm{kg}^{-1}$ of dicyandiamide, (I) Glomus mosseae $+50 \mathrm{mg} \mathrm{kg}^{-1}$ of dicyandiamide, (J) $100 \mathrm{mg} \mathrm{kg}^{-1}$ of dicyandiamide, (K) Piriformospora indica $+100 \mathrm{mg} \mathrm{kg}^{-1}$ of dicyandiamide, (L) Glomus etunicatum $+100 \mathrm{mg} \mathrm{kg}^{-1}$ of dicyandiamide, and (M) Glomus mosseae $+100 \mathrm{mg} \mathrm{kg}^{-1}$ of dicyandiamide.

\subsection{Effect of Dicyandiamide on Appearance of Leaves}

The use of concentrations of 50 and $100 \mathrm{mg} \mathrm{kg}^{-1}$ DCD caused margin burning of the lower leaves (primary leaves) of lettuce (Figure 10). These symptoms appeared in 100 and $50 \mathrm{mg} \mathrm{kg}^{-1}$ DCD treatments 14 and 21 days after transplanting, respectively. Thus, at $50 \mathrm{mg} \mathrm{kg}^{-1} \mathrm{DCD}$, leaf margin burn was not observed in lettuce plants inoculated with P. indica and G. etunicatum. In plants inoculated with G. mosseae after 18 days of seedling cultivation, leaf burn also appeared in the presence of a DCD inhibitory concentration of $50 \mathrm{mg} \mathrm{kg}^{-1}$. This burn was much lesser than that of noninoculated plants with symbiotic 
fungi at a concentration of $50 \mathrm{mg} \mathrm{kg}^{-1} \mathrm{DCD}$. The use of DCD inhibitors at a concentration of $100 \mathrm{mg} \mathrm{kg}^{-1}$ caused burn marks on the leaves of all lettuce plants, but this burn in plants inoculated with P. indica, G. etunicatum, and G. mosseae was much lesser than that of noninoculated plants. In a study by Pal et al. [56], it was observed that $6.3 \%$ of DCD used in the meadow is absorbed by the plant roots within 37 days. They also stated that the plant could not metabolize the DCD inhibitor absorbed by the roots or leaves. The main reason for the harmful effects of DCD compared to other nitrification inhibitors is its use in higher concentrations, which causes side-effects on plant yield [4]. Recent research on the toxicity of DCD on plants has also shown the harmful effects of DCD on plant yield [6]. Leaf chlorosis has also been reported in plants such as clover [57] and lettuce [6]. Research has shown that DCD is absorbed by plants and that the plant cannot metabolize it. As a result, finding a way to prevent the absorption of DCD is an important issue in agriculture and the environment.
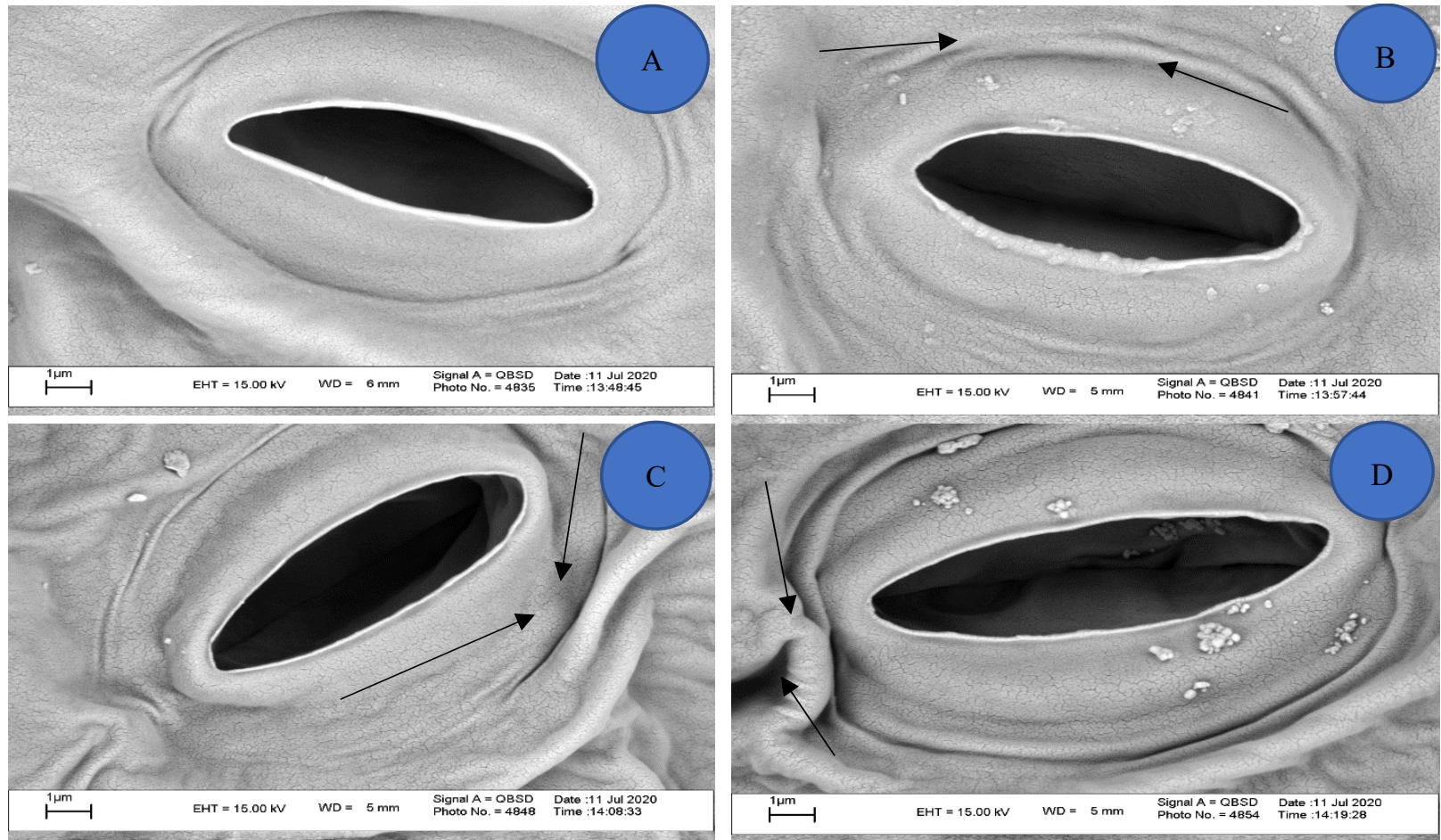

Figure 9. Effect of DCD on lettuce leaf stomata. (A) Control, (B) concentration of $5 \mathrm{mg} / \mathrm{kg}$ DCD in soil, (C) concentration of $50 \mathrm{mg} / \mathrm{kg}$ DCD in soil, and (D) concentration of $100 \mathrm{mg} / \mathrm{kg}$ DCD in soil.

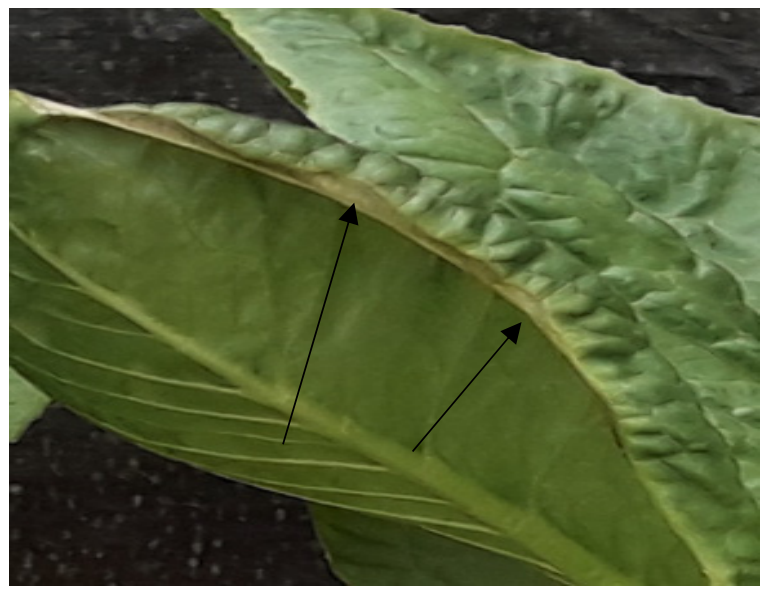

Figure 10. Effect of dicyandiamide on appearance of leaves. 


\section{Conclusions}

Our results showed that symbiotic fungi can, to some extent, prevent the accumulation of DCD nitrification inhibitor in the plant. In addition, the effects of DCD on the plant are very thought-provoking. Decreased root length, root colonization, and stomata area were among the significant effects of DCD at high concentrations (50 and $100 \mathrm{mg} \mathrm{kg}^{-1}$ ). However, the most important parameter that was the main purpose of this study was the concentration of DCD in the leaf and the effect that symbiotic fungi had on its reduction. According to the results, all fungi had some effect on reducing the absorption of DCD, and the greatest effect was related to the $P$. indica. This issue needs further research, and controlling the accumulation of nitrification inhibitors using organic methods can be the biggest challenge in agriculture.

Author Contributions: Conceptualization, R.A. and C.C.; methodology, A.P. and A.A.S.T.; validation, A.P., C.C. and R.A.; formal analysis, A.P. and R.A.; data curation, A.P. and R.A; writing—original draft preparation, A.P., C.C. and R.A.; writing-review and editing, C.C., R.A., B.E., A.P. and A.A.S.T.; supervision, R.A. and C.C.; project administration, R.A., funding acquisition, C.C., R.A. All authors have read and agreed to the published version of the manuscript.

Funding: The SOILdarity project has received funding from the European Union's Horizon 2020 research and innovation programme under grant agreement No 952051.

Institutional Review Board Statement: Not applicable.

Informed Consent Statement: Not applicable.

Data Availability Statement: The data that support the findings of this study are available from the corresponding author upon reasonable request.

Acknowledgments: We would like to thank the University of Mohaghegh Ardabili, Ardabil, Iran, for its support during the implementation of this project, which was also financially supported by Portuguese funds through Fundação para a Ciência e a Tecnologia (project UIDB/00329/2020).

Conflicts of Interest: The authors declare no conflict of interest.

\section{References}

1. Bock, E.; Wagner, M. Oxidation of Inorganic Nitrogen Compounds as an Energy Source. In The Prokaryotes; Rosenberg, E., DeLong, E.F., Lory, S., Stackebrandt, E., Thompson, F., Eds.; Springer: Berlin/Heidelberg, Germany, 2006; pp. 457-495.

2. Li, J.H.; Yu, X.Z.; Wu, S.C.; Wang, X.R.; Wang, S.H.; Tam, N.F.Y.; Wong, M.H. Responses of Bioaugmented Ryegrass to Pah Soil Contamination. Int. J. Phytoremed. 2011, 13, 441-455. [CrossRef] [PubMed]

3. Ruser, R.; Schulz, R. The effect of nitrification inhibitors on the nitrous oxide $(\mathrm{N} 2 \mathrm{O})$ release from agricultural soils-A review. J. Plant Nutr. Soil Sci. 2015, 178, 171-188. [CrossRef]

4. Yang, M.; Fang, Y.; Sun, D.; Shi, Y. Efficiency of two nitrification inhibitors (dicyandiamide and 3,4-dimethypyrazole phosphate) on soil nitrogen transformations and plant productivity: A meta-analysis. Science 2016, 6, 22075. [CrossRef] [PubMed]

5. Rodrigues, J.M.; Lasa, B.; Aparicio-Tejo, P.M.; González-Murua, C.; Marino, D. 3,4-Dimethylpyrazole phosphate and 2-(N-3,4dimethyl-1H-pyrazol-1-yl) succinic acid isomeric mixture nitrification inhibitors: Quantification in plant tissues and toxicity assays. Sci. Total Environ. 2018, 624, 1180-1186. [CrossRef] [PubMed]

6. Zerulla, W.; Barth, T.; Dressel, J.; Erhardt, K.; Horchler von Locquenghien, K.; Pasda, G.; Rädle, M.; Wissemeier, A.H. 3,4Dimethylpyrazole phosphate (DMPP) - A new nitrification inhibitor for agriculture and horticulture. An introduction. Biol. Fertil. Soils 2001, 34, 79-84. [CrossRef]

7. Lal, K.; Kumar, L.; Kumar, A.; Kumar, A. Oxazolone-1,2,3-Triazole Hybrids: Design, Synthesis and Antimicrobial Evaluation. Curr. Top. Med. Chem. 2018, 18, 1506-1513. [CrossRef] [PubMed]

8. Wani, P.A.; Omozele, A.B. Cr (VI) removal by indigenous Klebsiella species PB6 isolated from contaminated soil under the influence of various factors. Curr. Res. Bacteriol. 2018, 8, 62. [CrossRef]

9. Varma, A.; Sativa, S.; Sahay, N.; Butehorn, B.; Franken, P. Piriformospora indica, a cultivable plant growth-promoting root endophyte. Appl. Environ. Microbiol. 1998, 65, 2741-2744. [CrossRef]

10. Vadassery, J.; Tripathi, S.; Prasad, R.; Varma, A.; Oelmüller, R. Monodehydroascorbate reductase 2 and dehydroascorbate reductase 5 are crucial for a mutualistic interaction between Piriformospora indica and Arabidopsis. J. Plant Physiol. 2009, 166, 1263-1274. [CrossRef]

11. Yu, X.Z.; Wu, S.C.; Wu, F.Y.; Wong, M.H. Enhanced dissipation of PAHs from soil using mycorrhizal ryegrass and PAH-degrading bacteria. J. Hazard. Mater. 2011, 186, 1206-1217. [CrossRef] 
12. Gao, Y.; Li, Q.; Ling, W.; Zhu, X. Arbuscular mycorrhizal phytoremediation of soils contaminated with phenanthrene and pyrene. J. Hazard. Mater. 2011, 185, 703-709. [CrossRef] [PubMed]

13. Maftoun, M.; Sheibany, B. Comparative phytotoxicity of several nitrification inhibitors to soybean plants. J. Agric. Food Chem. 1979, 27, 1365-1368. [CrossRef]

14. Maftoun, M.; Banihashemi, Z. Effects of added sulfur, aluminium sulfate and ferrous sulfate on CO2 evolution, microbial population and nitrification in alfalfa-and straw-amended soil. Agrochimica 1981, 25, 318-326.

15. Hill, T.W.; Käfer, E. Improved protocols for Aspergillus minimal medium: Trace element and minimal medium salt stock solutions. Fungal Genet. Newsl. 2001, 48, 20-21. [CrossRef]

16. Hajiboland, R.; Aliasgharzadeh, N.; Laiegh, S.F.; Poschenrieder, C. Colonization with arbuscular mycorrhizal fungi improves salinity tolerance of tomato (Solanum lycopersicum L.) plants. Plant Soil 2010, 331, 313-327. [CrossRef]

17. Phillips, J.M.; Hayman, D.S. Improved procedures for clearing roots andstaining parasitic and vesicular-arbuscular mycorrhizal fungi for rapidassessment of infection. Trans. Br. Mycol. Soc. 1970, 55, 158-161. [CrossRef]

18. Giovannetti, M.; Mosse, B. An evaluation of techniques for measuring vesicular arbuscular mycorrhizal infection in roots. New Phytol. 1980, 84, 489-500. [CrossRef]

19. Arnon, A. Method of extraction of chlorophyll in the plants. Agron. J. 1967, 23, 112-121.

20. Kim, D.G.; Giltrap, D.; Saggar, S.; Palmada, T.; Berben, P.; Drysdale, D. Fate of the nitrification inhibitor dicyandiamide (DCD) sprayed on a grazed pasture: Effect of rate and time of application. Soil Res. 2012, 50, 337-347. [CrossRef]

21. Yadav, I.C.; Devi, N.L.; Syed, J.H.; Cheng, Z.; Li, J.; Zhang, G.; Jones, K.C. Current status of persistent organic pesticides residues in air, water, and soil, and their possible effect on neighboring countries: A comprehensive review of India. Sci. Total Environ. 2015, 511, 123-137. [CrossRef]

22. Coppola, L.; Comitini, F.; Casucci, C.; Milanovic, V.; Monaci, E.; Marinozzi, M.; Taccari, M.; Ciani, M.; Vischetti, C. Fungicides degradation in an organic biomixture: Impact on microbial diversity. New Biotechnol. 2011, 29, 99-106. [CrossRef] [PubMed]

23. Maienza, A.; Bååth, E.; Stazi, S.R.; Benedetti, A.; Grego, S.; Dell'Abate, M.T. Microbial dynamics after adding bovine manure effluent together with a nitrification inhibitor (3,4 DMPP) in a microcosm experiment. Biol. Fertil. Soils 2014, 50, 869-877. [CrossRef]

24. Florio, A.; Maienza, A.; Dell'Abate, M.T.; Stazi, S.R.; Benedetti, A. Changes in the activity and abundance of the soil microbial community in response to the nitrification inhibitor 3,4-dimethylpyrazole phosphate (DMPP). J. Soils Sediments 2016, 16, 2687-2697. [CrossRef]

25. Xiuzhen, S.; Hang-Wei, H.; Zhu-Barker, X.; Hayden, H.; Wang, J.; Suter, H.; Chen, D.; Ji-Zheng, H. Nitrifier-induced denitrification is an important source of soil nitrous oxide and can be inhibited by a nitrification inhibitor 3,4-dimethylpyrazole phosphate. Environ. Microbiol. 2017, 19, 4851-4865.

26. Sigler, W.V.; Turco, R.F. The impact of chlorothalonil application on soil bacterial and fungal populations as assessed by denaturing gradient gel electrophoresis. Appl. Soil Ecol. 2002, 21, 107-118. [CrossRef]

27. Evelin, H.; Kapoor, R. Arbuscular mycorrhizal symbiosis modules antioxidant response in salt stressed Trigonella foenumgraecum plants. Mycorrhiza 2014, 24, 197-208. [CrossRef]

28. Sharma, P.; Kharkwal, A.C.; Abdin, M.Z.; Varma, A. Piriformospora indica-mediated salinity tolerance in Aloe vera plantlets. Symbiosis 2016, 72, 103-115. [CrossRef]

29. Yu, Q.; Ma, J.; Zou, P.; Lin, H.; Sun, W.; Yin, J.; Fu, J. Effects of combined application of organic and inorganic fertilizers plus nitrification inhibitor DMPP on nitrogen runoff loss in vegetable soils. Environ. Sci. Pollut. Res. 2015, 22, 472-481. [CrossRef]

30. Marschner, H. Marschner's Mineral Nutrition of Higher Plants; Marschner, P., Ed.; Academic Press: New York, NY, USA, 2011.

31. García, I.V.; Mendoza, R.E. Relationships among soil properties, plant nutrition and arbuscular mycorrhizal fungi-plant symbioses in a temperate grassland along hydrologic, saline and sodic gradients. FEMS Microbiol. Ecol. 2008, 63, 359-371. [CrossRef]

32. Ray, P.; Abraham, P.E.; Guo, Y.; Giannone, R.J.; Engle, N.L.; Yang, Z.K.; Craven, K.D. Scavenging organic nitrogen and remodelling lipid metabolism are key survival strategies adopted by the endophytic fungi, Serendipita vermifera and Serendipita bescii to alleviate nitrogen and phosphorous starvation in vitro. Environ. Microbiol. Rep. 2019, 11, 548-557. [CrossRef]

33. Teutscherova, N.; Vazquez, E.; Arango, J.; Arevalo, A.; Benito, M.; Pulleman, M. Native arbuscular mycorrhizal fungi increase the abundance of ammonia-oxidizing bacteria, but suppress nitrous oxide emissions shortly after urea application. Geoderma 2018, 338, 493-501. [CrossRef]

34. Marsden, K.A.; Scowen, M.; Hill, P.W.; Jones, D.L.; Chadwick, D.R. Plant acquisition and metabolism of the synthetic nitrification inhibitor dicyandiamide and naturally- occurring guanidine from agricultural soils. Plant Soil 2015, 395, 201-214. [CrossRef]

35. Pal, P.; McMillan, A.M.S.; Saggar, S. Pathways of dicyandiamide uptake in pasture plants: A laboratory study. Biol. Fertil. Soils 2016, 52, 539-546. [CrossRef]

36. Vilsmeier, K. Fate of ammonium-N in pot studies as affected by DCD addition. Fert. Res. 1991, 29, 187-189. [CrossRef]

37. Padash, A.; Shahabivand, S.; Behtash, F.; Aghaee, A. A practicable method for zinc enrichment in lettuce leaves by the endophyte fungus Piriformospora indica under increasing zinc supply. Sci. Hortic. 2016, 213, 367-372. [CrossRef]

38. Sharaf-Eldin, M.A.; Elkholy, S.; Fernández, J.A.; Junge, H.; Cheetham, R.D.; Guardiola, J.L.; Weathers, P.J. The effect of Bacillus subtilis FZB24®on flowers quantity and quality of saffron (Crocus sativus L.). Planta Medica 2007, 73, P_607. [CrossRef] 
39. Tanha, S.R.; Ghasemnezhad, A.; Babaeizad, V. A study on the effect of endophyte fungus, Piriformospora indica, on the yield and phytochemical changes of globe artichoke (Cynara scolymus L.) leaves under water stress. Int. J. Adv. Biol. Biomed. Res. 2014, 2, 1907-1921.

40. Rathod, D.P.; Brestic, M.; Shao, H.B. Chlorophyll a fluorescence determines the drought resistance capabilities in two varieties of mycorrhized and non-mycorrhized Glycine max Linn. Afr. J. Microbiol. Res. 2011, 5, 4197-4206. [CrossRef]

41. Reeves, D.W.; Touchton, J.T. Relative Phytotoxicity of Dicyandiamide and Availability of its Nitrogen to Cotton, Corn, and Grain Sorghum. Soil Sci. Soc. Am. J. 1986, 50, 1353-1357. [CrossRef]

42. Lawlor, D.W.; Cornic, G. Photosynthetic carbon assimilation and associated metabolism in relation to water deficits in higher plants. Plant Cell Environ. 2002, 25, 275-294. [CrossRef]

43. Lenoir, I.; Lounes-Hadj Sahraoui, A.; Laruelle, F.; Dalpe, Y.; Fontaine, J. Arbuscular mycorrhizal wheat inoculation promotes alkane and polycyclic aromatic hydrocarbon biodegradation: Microcosm experiment on aged-contaminated soil. Environ. Pollut. 2016, 213, 549-560.

44. Sainz, M.J.; Gonzalez, P.B.; Vilarino, A. Effects of hexachlorocyclohexane on rhizosphere fungal propagules and root colonization by arbuscular mycorrhizal fungi in Plantago lanceolata. Eur. J. Soil Sci. 2006, 57, 83-90. [CrossRef]

45. Liu, J.; Liu, J.; Liu, J.; Cui, M.; Huang, Y.; Tian, Y.; Chen, A.; Xu, G. The Potassium Transporter SlHAK10 Is Involved in Mycorrhizal Potassium Uptake. Plant Physiol. 2019, 180, 465-479. [CrossRef] [PubMed]

46. Binet, P.; Portal, J.M.; Leyval, C. Application of GC-MS to the study of anthracene disappearance in the rhizosphere of ryegrass. Org. Geochem. 2001, 32, 217-222. [CrossRef]

47. Aranda, E.; Scervino, J.M.; Godoy, P.; Reina, R.; Ocampo, J.A.; Wittich, R.M.; García-Romera, I. Role of arbuscular mycorrhizal fungus Rhizophagus custos in the dissipation of PAHs under root-organ culture conditions. Environ. Pollut. 2019, 181, 182-189. [CrossRef] [PubMed]

48. Zhou, X.; Zhou, J.; Xiang, X. Impact of four plant species and arbuscular mycorrhizal (AM) fungi on polycyclic aromatic hydrocarbon (PAH) dissipation in spiked soil. Polish J. Environ. Stud. 2013, 22, 1239-1245.

49. Fatma, M.; Masood, A.; Per, T.S.; Khan, N.A. Nitric oxide alleviates salt stress inhibited photosynthetic performance by interacting with sulfur assimilation in mustard. Front. Plant Sci. 2016, 7, 521. [CrossRef]

50. Per, T.S.; Masood, A.; Khan, N.A. Nitric oxide improves S-assimilation and GSH production to prevent inhibitory effects of cadmium stress on photosynthesis in mustard (Brassica juncea L.). Nitric Oxide 2017, 68, 111-124. [CrossRef]

51. Sehar, Z.; Masood, A.; Khan, N.A. Nitric oxide reverses glucose-mediated photosynthetic repression in wheat (Triticum aestivum L.) under salt stress. Environ. Exp. Bot. 2019, 16, 277-289. [CrossRef]

52. Fatma, M.; Khan, M.I.R.; Masood, A.; Khan, N.A. Coordinate changes in assimilatory sulfate reduction are correlated to salt tolerance: Involvement of phytohormones. Annu. Rev. Res. Biol. 2013, 3, 267-295.

53. Asgher, M.; Per, T.S.; Masood, A.; Fatma, M.; Freschi, L.; Corpas, F.J.; Khan, N.A. Nitric oxide signaling and its crosstalk with other plant growth regulators in plant responses to abiotic stress. Environ. Sci. Pollut. Res. Int. 2017, 24, 2273-2285. [CrossRef] [PubMed]

54. Wu, D.; Cárdenas, L.M.; Calvet, S.; Brüggemann, N.; Loick, N.; Liu, S.; Bol, R. The effect of nitrification inhibitor on $\mathrm{N}_{2} \mathrm{O}, \mathrm{NO}$ and $\mathrm{N}_{2}$ emissions under different soil moisture levels in a permanent grassland soil. Soil Biol. Biochem. 2017, 113, 153-160. [CrossRef]

55. Vahabi, K.; Dorcheh, S.K.; Monajembashi, S.; Westermann, M.; Reichelt, M.; Falkenberg, D.; Hemmerich, P.; Sherameti, I.; Oelmüller, R. Stress promotes Arabidopsis-Piriformospora indica interaction. Plant Signal. Behav. 2016, 11, 1136763. [CrossRef] [PubMed]

56. Pal, P.; McMillan, A.; Saggar, S. Routes of Dicyandiamide Uptake in Pasture Plants: A Preliminary Laboratory Study. Int. Grassl Congr. Proc. 2020, 28, 1-9.

57. Macadam, X.M.B.; Del Prado, A.; Merino, P.; Estavillo, J.M.; Pinto, M.; González-Murua, C. Dicyandiamide and 3,4-dimethyl pyrazole phosphate decrease $\mathrm{N}_{2} \mathrm{O}$ emissions from grassland but dicyandiamide produces deleterious effects in clover. J. Plant Physiol. 2003, 160, 1517-1523. [CrossRef] [PubMed] 